\title{
Managing knowledge to create customer service value
}

\begin{tabular}{|r|l|}
\hline Journal: & Journal of Service Theory and Practice \\
\hline Manuscript ID: & MSQ-06-2014-0137.R5 \\
\hline Manuscript Type: & Research Paper \\
\hline Keywords: & $\begin{array}{l}\text { Service value, Knowledge management, Banking industry, Value creation, } \\
\text { Absorptive capacity }\end{array}$ \\
\hline \multicolumn{2}{|l}{} \\
\hline
\end{tabular}

SCHOLARONE ${ }^{\text {m }}$

Manuscripts 


\section{Managing knowledge to create customer service value}

\section{Purpose}

The purpose of this paper is to contribute to the services management literature by identifying a sequence of the different processes of knowledge management to create customer service value.

\section{Design/methodology/approach}

The context for the research hypotheses is the Spanish banking industry. The authors conducted a study including 76 banks and 1832 customers of these banks. This paper uses the partial least squares (PLS) method to conduct the data analysis.

\section{Findings}

The authors find support for all the hypotheses proposed in the model. The results show that service firms that are able to apply more knowledge or apply knowledge more effectively are likely to generate more benefits for their customers, and/or reduce their sacrifices, contributing significantly to a higher perception of service value.

\section{Research limitations/implications}

The study focuses on one particular industry in a single point in time. A longitudinal analysis of a variety of service industries would enrich the study.

\section{Practical implications}

It is argued that knowledge management constitutes a key capability for service firms for the delivery of service value. According to the research, if service firms want to improve the application of knowledge, it is important to focus on knowledge retention while they create new knowledge.

\section{Originality/value}

Although a considerable amount of research has been carried out in the fields of knowledge management and customer value, there has been less research that has taken both into consideration simultaneously. This paper addresses this gap in the literature.

\section{Keywords:}

Service value, Knowledge management, Banking industry, Value creation, Absorptive capacity.

\section{Introduction}

Although a considerable amount of research has been carried out in the field of knowledge management (KM) (e.g. Brown and Duguid, 2001; Lages et al., 2013; Lavergne and Earl, 2006; Spender, 2006; Spender and Scherer, 2007; Storey and Hull, 2010) and in the field of customer perceived value (e.g. Agarwal and Teas, 2001; 
Boksberger and Melsen, 2011; Cengiz and Kirkbir, 2007; Mustak et al., 2013; Sánchez and Iniesta, 2006), there has been less research that has taken both into consideration simultaneously.

In this paper, the authors propose that managers should focus on KM by considering $\mathrm{KM}$ as an organizational capability that views the customer as the key component that could help firms create maximum customer value.

According to Edvardsson and Oskarsson (2011), the link between KM and value creation has not been fully explored. Although there has been discussion in recent literature of the relationship between KM and customer value (Gebert et al., 2003; Kaplan and Norton, 2004; Rezgui, 2007), it has taken the firm's perspective without asking customers about their perception of value. In other words, Edvardsson and Oskarsson (2011) have focused on the relationship between KM and the creation of value for firms, but not for customers. Moreover, Vorakulpipat and Rezgui (2008) suggest that KM processes have inherent value creation capabilities, but some questions still remain over this theoretical justification.

This study addresses the gap in the literature by identifying possible combinations of the different processes of $\mathrm{KM}$ and trying to propose and analyze a sequence of $\mathrm{KM}$ processes for increasing the value perceived by customers. The specific research question is: how should service firms manage their knowledge in order to improve the provision or delivery of service value to customers? A key asset of our research is that we were able to test our model following a multi-informant approach (linking the internal perceptions of KM practices of managers and the outcome to the perceptions of external customers).

In short, the paper aims to contribute to the service management literature by determining the relationship between the different processes of KM and the potential 
effects of this relationship in the creation of service value; it uses a survey of Spanish banks' customers and managers for the empirical study. The banking industry is saturated with information - it is at the very core of all of its services. Bank managers try to capture that information so they can turn it into organizational knowledge that can be exploited as a competitive advantage. KM practices are essential given the increasing complexity of the banking environment, and although its application does not really differ from other service industries (such as insurance, medical services, etc.), its implementation poses challenges that make this industry a perfect service setting to conduct a KM study.

The paper is organized as follows. The first section gives an explanation of the theoretical context. Next, the presentation of the study model and the development of the hypotheses follow. Then, a description of the principal aspects of the methodology (such as the research context, measures, data collection and the data analysis technique) is presented. This is followed by the results of the study. The paper concludes with a summary of the major findings, any managerial implications, the limitations of the study, and possible areas for further research.

\section{Theoretical background}

\section{Knowledge management (KM) in the banking industry}

Understanding how firms create and maintain a competitive advantage is fundamental in the strategic management field (Zott, 2003). Academics suggest that when firms have resources and capabilities, which are valuable, rare, inimitable and non-substitutable (VRIN), they can use them to implement value creation strategies that can lead to a sustainable competitive advantage (Barney, 1991). Many theories have been advanced regarding sources of competitive advantage, such as the competitive forces approach (Porter, 1985), the resource-based view (RBV) (Barney, 1991; Mahoney and Pandian, 
1992; Peteraf, 1993), and the knowledge-based view of the firm (KBV) (Alavi and Leidner, 2001; Grant, 1996).

The focus of this paper is on the KBV which identifies knowledge as the firm's most strategically significant resource. The KBV emerges as an important issue in the service management field as it offers a theoretical basis in which knowledge-based resources play an important role in increasing the sustainable competitiveness of service firms (Chang Lee et al., 2005; Chaston, 2012; Hu et al., 2013; Lara et al., 2012).

Knowledge is an intangible resource; the alignment and integration of intangible resources in a firm, although complex, is crucial with regard to value creation (Kaplan and Norton, 2004). Given the importance of firms' intangible resources, ways must be found of managing them (Spender, 2006). KM emerges as the management of these intangible resources, versus the previous management of tangible ones (Spender and Scherer, 2007).

We define $\mathrm{KM}$ as an organizational capability that allows the integration of people, technologies, processes and strategies within the firm to create, use and share the knowledge that firms need in order to improve operational efficiency, to innovate, and to sense and respond to new opportunities in the marketplace (Chen and Huang, 2009; Chou et al., 2007; Gold et al., 2001; Lin, 2007).

KM processes have become indispensable to the banking sector (Ugurlu and Kizildag, 2013). The most common fields of KM applications in banking are risk management, customer relationship management, performance management (for stakeholders), and service operations (Alrawi and Elkhatib, 2009). Despite some difficulties in the application of KM practices in banking, there have been major investments in decision support systems, data warehouses, and data mining; and the use 
of information technology (IT) has given a new dimension to KM. We discuss each KM process and provide illustrations in the banking industry next.

\section{KM processes}

Based on a review of the existing literature (Argote et al., 2003; Chang Lee et al., 2005; Chen and Huang, 2009; Gold et al., 2001; Huang and Li, 2009; Ipe, 2003; Lin, 2007), we found that there are discrepancies in terms of the number and labeling of the processes involved in the management of knowledge in firms (Alavi and Leidner, 2001). However, it is clear that three key KM processes, at least, must be considered: 1) knowledge creation, 2) knowledge storage/transfer, and 3) knowledge application.

Knowledge creation. We identify many terms that have been used to describe the process of knowledge creation in firms, such as knowledge acquisition (Cui et al., 2005; Gold et al., 2001; Jantunen, 2005; Lin, 2007; Lin and Lee, 2005), knowledge generation (Grover and Davenport, 2001), knowledge building (Demarest, 1997), and knowledge construction (McAdam and McCreedy, 1999).

In this paper, knowledge creation is defined as 'the accumulation of knowledge in the firm resulting from its ability to absorb external knowledge'. Hence, knowledge creation in this paper refers to the absorptive capacity of firms.

The first to introduce the concept of absorptive capacity (i.e. the ability of a firm to absorb external knowledge) were Cohen and Levinthal (1990). This concept was introduced to explain why some firms are better able to take advantage of available external knowledge compared to others in the industry (McDonald and Madhavaram, 2007). The absorptive capacity of the firm (Cohen and Levinthal, 1990; Liao et al., 2010) is critical to its success since the accumulation of knowledge is a result of not only the internal development of knowledge, but also the assimilation of external knowledge (Ritala et al., 2013). In this way, we argue that absorptive capacity is closely 
related to the process of creating knowledge. Zahra and George (2002) distinguish between a firm's potential and realized absorptive capacity. On the one hand, potential absorptive capacity (PACAP) makes the firm receptive to acquiring and assimilating external knowledge but does not guarantee the exploitation of this knowledge. On the other hand, realized absorptive capacity (RACAP) reflects the firm's capacity to utilize the knowledge that has been absorbed.

Banks and other players in the competitive financial services industry have recognized that knowledge is power. Such knowledge covers the full range from an organization's own intellectual capital (degree of expertise) to the data from any customer transaction (Jayasundara, 2008). For instance, bank managers face decisions on what projects to finance - risk management - as well as designing financial products and services that can be tailored to meet customer needs in order to raise funds. The bank performance is heavily dependent on carefully assessing the risk involved in major financial operations. For example, several savings banks in Spain needed to be rescued by the European Union (EU) because of their heavy reliance on real estate assets that depreciated and became toxic assets (unlikely or impossible to get back). And even though the big players in the Spanish banking industry did not need to be rescued, their market performance also suffered (Carbó et al., 2011).

In addition, best customer relationship management practices require the gathering and storing of information regarding the actual and potential profitability of customers, including their wealth, loyalty, share of wallet, and personal affairs, all of which may have an impact on their financial worth (Du et al., 2007). Front-line employees are in the right position to put this information into the system, generating customer knowledge that can lead to a competitive advantage when properly managed (Homburg et al., 2009). 
Bank performance is also heavily dependent on the costs of service operations. The globalization of financial markets forced bankers to be more efficient in managing knowledge in their banking operations. Without proper information management systems, procedures and tools, large amounts of information may become a serious issue that could result in less reactive responses, inefficiency, and a decline in the bank’s capacity to deliver high quality services (Mohsen et al., 2011).

Knowledge storage/transfer. Many terms have been used to describe knowledge storage and transfer, such as knowledge embodiment (McAdam and McCreedy, 1999), knowledge retention (Argote et al., 2003), knowledge dissemination (Chou et al., 2007; Jantunen, 2005; Lages et al., 2013), knowledge sharing (Earl, 2001), knowledge codification (Baskerville and Dulipovici, 2006; Grover and Davenport, 2001), knowledge distribution (Bhatt, 2001), knowledge conversion (Cui et al., 2005; Gold et al., 2001; Lin, 2007), and organizational memory (Chou et al., 2007). The aim of such a process is to make knowledge available or accessible to those who need it (Davenport and Prusak, 1998).

To make knowledge available it is crucial that individuals and departments are involved in the process of knowledge transfer (De Vries et al., 2006; O'Dell and Grayson, 1998; Osterloh and Frey, 2000). Knowledge transfer among employees is seen as an effective way of acquiring local knowledge (Gold et al., 2001), and improving the knowledge that a firm has about its competitors and the industry as a whole.

Knowledge storage/transfer consists of the retention of stored information from an organization's history and its quick and easy access in order to be applied to present decisions. Therefore, when we speak of knowledge storage/transfer we are referring to the idea of organizational memory. 
Researchers and practitioners recognize organizational memory as an important factor in the success of a firm's operations, and in its reactions to the changes and challenges of the environment (Nilakanta et al., 2006). As such, organizational memory is simply a collection of knowledge stored in different places in a firm (Walsh and Ungson, 1991). For knowledge to be used in a firm's decision-making, KM must allow access to that knowledge.

Firms create knowledge and learn, but they also forget; that is, firms can lose track of acquired knowledge (Argote et al., 1990; Darr et al., 1995). If knowledge created for years through KM activities is not transferred and retained systematically, it cannot be beneficial to any future decision-making (Chang Lee et al., 2005). Therefore, the knowledge storage/transfer process, also referred to as organizational memory, constitutes an important aspect of effective KM (Chou, 2005).

In many working environments, the best decisions depend on circumstances and available knowledge, which drives the need to think about decision-making and problem solving at any level (managers, employees) in the banking company. Decisions based on past experiences may not be the most appropriate ones, so there is a need to know-how, know-what, know-where, and know-why to respond to market demands. Banking companies must deliver the right service at the right time to the right customer. Customer-focused strategies need high performance organizational practices and must grant access to this information when needed in order to be effective. Technology is developing quickly in order to allow knowledge sharing anytime and anywhere. Intranets, data warehouses, mobile technology, portable hardware and software, emails, and networks are just some of the technologies that are commonly used for knowledge storage/transfer in banking. But equally important is training people to share their own individual knowledge and expertise, especially when company culture has not fully 
embraced the principles of KM (Ali and Ahmad, 2006). Knowledge sharing individually or collectively by banking staff adds value when $\mathrm{KM}$ is practiced in a knowledge-intensive organization (Alrawi and Elkhatib, 2009).

Knowledge application. Many terms are used to describe the process of knowledge application, such as knowledge leverage (Ipe, 2003), knowledge use (Earl, 2001), and knowledge utilization (Chang Lee et al., 2005; Jantunen, 2005). In this paper, we refer to knowledge application as 'the process of making knowledge active and relevant for the firm in offering service value. It involves using knowledge in support of decisions, actions, and problem solving'.

Although several authors (Cui et al., 2005; Gold et al., 2001; Lin, 2007; Lin and Lee, 2005) do not make a distinction between the processes of knowledge application and knowledge storage/transfer, we are going to consider them separately due to their importance for effective KM. The application of knowledge implies the use of knowledge generated in the phase of knowledge creation and retained in the phases of storage and transfer. Therefore, knowledge application entails the internalization of knowledge in a firm.

For example, best practice in customer relationship management is to nurture customers so that they become more loyal and profitable (Rust et al., 2004). One way to do this in banking is through cross-selling different financial products. When banks use their stored information wisely - applying that knowledge - the success rate of crossselling campaigns increases (Blattberg et al., 2001). For instance, a bank knows your age; they also usually know where you work and how much your regular income is. They may also know that your current expenses may not allow you to save much at the end of the month, especially because of any mortgage you may already have with them. However, they may keep offering private funding plans, stocks operation services, etc... 
even though you are not interested at all because you have no money to invest. In conclusion, therefore, it is one thing for a bank to store the right information but quite another for it to apply that knowledge and utilize it properly.

\section{Service value}

During the 1990 s and continuing into the 2000s, the issue of value creation and the delivery of value for customers have become increasingly important in the management and marketing literature (Grönroos and Ravald, 2011; Wang et al., 2003).

Traditionally, the principal mechanism for listening to the customer has been to measure quality and satisfaction. Woodruff (1997) states that the measurement of satisfaction needs to shift towards a better understanding of what customers value in terms of which services help them to achieve their organizational goals and purposes. As a result, many researchers are now focusing on customer perceived value (Agarwal and Teas, 2001; Boksberger and Melsen, 2011; Cengiz and Kirkbir, 2007; IniestaBonillo et al., 2012; Sánchez and Iniesta, 2006).

Over the last few decades, service firms have found themselves in a new and complex competitive environment, in which customers increasingly demand higher value (Sánchez et al., 2009). The literature discusses at some length this growing interest in the creation and provision of superior customer value (Mustak et al., 2013; Smith and Colgate, 2007; Wang et al., 2004) by partially replacing more limited concepts such as quality (Cronin et al., 2000) or satisfaction (Woodruff, 1997).

In this way, customer value becomes a customer-oriented concept. The customer's perception of what is created and delivered should be established and borne in mind when the firm defines its value proposition (Payne and Holt, 2001). Today, customers are considered co-producers and co-creators of value (Gebauer et al., 2010; Wang et al., 2004). 
Service value can be defined as a trade-off between the quality and benefits that customers perceive in a service relative to the sacrifice they associate with acquiring it (Monroe, 1990). Hence, service value consists of various benefits and sacrifices, and represents a higher-order (multidimensional) construct that refers to the role of the service components in shaping customers' perceptions of value. That is, perceived value results from consumers cognitively integrating any perceived benefits with perceived costs, and depends on a combination of monetary and non-monetary sacrifices, quality, performance, and disconfirmation experiences.

Woodruff (1997) proposes that value stems from customers' learned perceptions, preferences, and evaluations. This view depicts service value as a hierarchy or means-end chain that begins with customers thinking about desired attributes and performance and builds to goal-directed and purposeful behavior or their satisfaction with the received value (Martin et al., 2008). In addition, service value is a construct too complex to be operationalized as one-dimensional (Lam et al., 2004; Wang et al., 2004). Thus, it is necessary to use a multidimensional approach to consider its multiple components of benefits and sacrifices. We identify service quality, service equity, and confidence benefits as the essential benefit components of service value creation in banking. With regard to sacrifice components, we consider price fairness evaluations (monetary sacrifices) and service convenience (non-monetary sacrifices).

Delivering service quality is essential in today's competitive banking environment. Service quality heavily depends on bank employees' behavior and their interactions with customers. $\mathrm{KM}$ is an excellent tool to improve the knowledge and expertise of employees, motivating and empowering them to solve customer problems, which is essential to the delivery of high quality services. 
Service equity captures the bank's corporate reputation in the market. A bank's reputation is built over many years of good practice. The bank's organizational culture, values, and leadership affect the bank's image from the corporate level to managers and front-line employees. Efficient and effective $\mathrm{KM}$ is emphasized in the literature related to organizational culture and leadership (Ugurlu and Kizildag, 2013).

Confidence benefits underline the customer's trust. Trust is the key in long-term bank-customer relationships. A customer's trust is generated over continuous satisfactory experiences, which are dependent on customer needs knowledge (Homburg et al., 2009), and managers' degree of expertise in their markets. In banking services, the degree of expertise is usually unbalanced in the employee-customer dyadic relationship, which may lead to opportunistic behavior (Singh and Sidershmukh, 2000). For instance, in Spain many customers were 'fooled' by their banks (who pressured their employees) when they bought risky products (stock options) without knowing they were doing so, and lost their life savings in the process.

Prices of banking services are not always easy to compare for the customer. Knowledge about customers and competition is essential in guiding the pricing policy of banking services, especially when customer relationship principles are followed. Alternatively, the efficiency of service operations influences the cost structure of the banking company, which affects its price competitiveness. Banks are investing in IT developments in order to save time and money in their daily service operations.

Finally, a banking service is functional by nature (Bowen, 1990). Banking services have begun to occupy quite a large part of people's daily lives. Customers want their problems solved in a timely and effortless manner. Service convenience is about making life easier for the customer. For instance, the fast development of e-banking is tailored to those customers whose time-sensitivity is high. Similarly, ATMs are able to 
perform more daily operations than ever today. IT has enabled the creation of these new interfaces for customers, and these have also helped banks to cut their operational costs and become more competitive by focusing on different services that add value for the customer (Ugurlu and Kizildag, 2013).

\section{Conceptual model}

Service firms are aware of customer demand for superior value and need to understand how to manage knowledge so that they can satisfy these customer demands. A review of the previous literature shows numerous possible relationships between the different KM processes. After a comprehensive analysis of these possible relationships, the authors propose the following model:

\section{Please insert Figure 1 here}

As we have said before, Zahra and George (2002) distinguish between PACAP and RACAP. On the one hand, PACAP is a function of the acquisition and assimilation capabilities of a firm. Acquisition refers to a firm's ability to identify and acquire externally generated knowledge that is critical to its operations. Assimilation refers to the firm's routines and processes that allow it to analyze, process, interpret, and understand the information obtained from external sources.

On the other hand, RACAP is a function of the transformation and exploitation capabilities of a firm. Transformation denotes a firm's ability to develop and refine the routines that facilitate combining existing knowledge with the newly acquired and assimilated knowledge. This is accomplished by adding or deleting knowledge or simply by interpreting the same knowledge in a different manner. Exploitation is based on the routines that allow firms to refine, extend, and utilize existing competencies or to create new ones by incorporating acquired and transformed knowledge into service operations. 
As can be seen in Figure 1, knowledge creation is divided into the two aforementioned types of absorptive capacities. Hence, KM starts with the acquisition and assimilation of external knowledge (i.e. PACAP). Once knowledge is acquired and assimilated, service firms should retain it (i.e. knowledge storage/transfer).

Once knowledge is acquired and assimilated, and then stored, the next step must be the transformation and exploitation of this knowledge; that is, service firms need to utilize the knowledge that has been absorbed. This means that it is important for service firms to develop an 'absorptive capacity', that is the ability to use prior knowledge to recognize the value of new information, assimilate and apply it to create new knowledge and capabilities (Cohen and Levinthal, 1990). The next KM process is what we have referred to as RACAP. Hence, we predict a mediating role for knowledge storage/transfer in the relationship between PACAP and RACAP. In other words, we propose that the influence of PACAP on RACAP is partially mediated by knowledge storage/transfer. Finally, service firms will be able to actually use what they know in order to increase the perception of service value.

In summary, KM constitutes a key capability for service firms with regard to the delivery of service value. But for KM to impact on service value (creating customer benefits and/or reducing sacrifices), the relationship between the different $\mathrm{KM}$ processes must be as we have already stated (see Figure 1).

We therefore propose the following hypotheses:

$H_{1}$ : Potential Absorptive Capacity (PACAP) is directly and positively related to Realized Absorptive Capacity (RACAP) of the service company.

$H_{2}$ : The relationship between Potential Absorptive Capacity (PACAP) and Realized Absorptive Capacity (RACAP) would be mediated by the knowledge storage/transfer of the service company. 
$H_{3}$ : Knowledge application of the service company is directly influenced by its Realized Absorptive Capacity (RACAP).

$H_{4.1}$ : Knowledge application of the service company is positively related to the customer's perceived benefits of service value.

$H_{4.2}$ : Knowledge application of the service company is negatively related to the customer's perceived sacrifices of service value.

\section{Methodology \\ Industry selection}

The context for the research hypotheses is the Spanish banking industry in 2010, including retail and commercial banks and savings banks that serve the general public, representing around $18 \%$ of the national GDP. The crisis in the financial services industry is highly significant (both now and at the time when the study took place). The effect of this crisis has forced many countries to apply severe measures to reduce the impact on their financial services industry. Numerous bank and insurance company takeovers and capitalizations have taken place; the number of company mergers as a rescue measure has multiplied and crashes have increased.

Banking is a very knowledge-intensive service industry and, therefore, an appropriate one in which to identify, analyze, and evaluate the different KM processes. Due to the increasingly intense competition within the financial services industry, it has become imperative that banks focus on continuously improved service value if they are to remain competitive. In addition to the competitiveness of the industry, the relative intangibility and information-based nature of their core services creates the need to capture and retain customers by offering them something extra (i.e. KM).

Data collection 
Data to test the organizational capabilities proposed in our study were collected from the general manager in the main office of the retail and commercial banks, and savings banks that appeared in the List of Entities from the Bank of Spain in 2010 (published by the Bank of Spain). This respondent profile was chosen after holding several meetings with banking experts. Following their advice, we concluded that the main office general managers were well prepared to answer all the questions in the questionnaire because they have a broad perspective, both of the bank as a whole, and of the different activities and strategies developed by the bank.

After collecting data from the banks, we also gathered data from banking customers to gain a precise picture of the value generated by the firms.

We decided to integrate these two sources of data (bank and customer) to test our hypotheses. This multi-informant approach limits banks' self-attribution biases.

\section{Sample data}

The total number of banks operating in Spain at the time of the study was 110, of which 65 were commercial/retail banks, and 45 were savings banks. The small number of players making up the banking industry in Spain could be seen as an advantage as the study was able to examine the whole population instead of a particular sample.

Only 85 of the banks met the requirements of the study (i.e. banks serving the general public). Therefore, the target group consisted of 85 financial companies, representing around $77 \%$ of the total. The response rate was high, at around $90 \%$, with 76 of the 85 banks completing the questionnaire by personal interview with the general manager in the main office. We only made use of completed questionnaires. Furthermore, because the data sample (76) was very close to the real population in the Spanish banking industry (85), we used factor correction to adapt the standard error generated as suggested by Malhotra and Birks (2006). 
A pool of customer data (with a minimum of 20 customers) was obtained for each of the banks under study (76) to observe standard customer behavior regarding service value. The study used 1832 customer questionnaires.

\section{Measures}

We created our own scale to measure KM, taking items from several scales used in previous investigations. As mentioned previously, three key dimensions stand out from the literature review as affecting KM processes: knowledge creation, knowledge storage/transfer, and knowledge application.

We opted for an absorptive capacity scale as proposed by Jansen et al. (2005) to measure knowledge creation. This scale consists of nine items to measure PACAP (six items for the acquisition component and three items for the assimilation component), and 12 items to measure RACAP (six items for the transformation component and six items for the exploitation component). The final refined scale consists of eight items for the PACAP dimension (five for acquisition and three for assimilation), and eight items for the RACAP dimension (four for transformation and four for exploitation) (see Appendix 1).

To measure knowledge storage/transfer, the authors use Chou et al.'s (2007) scale, which consists of four items and measures organizational memory. Organizational memory refers to the processing of saved knowledge, a concept that coincides with our understanding of knowledge storage and transfer. The refined scale retains the four items (see Appendix 1).

The model uses Gold et al.'s (2001) scale to measure knowledge application. The knowledge application scale consists of 12 items. After cleaning the data, this scale includes 10 items (see Appendix 1). 
The model uses Martin et al.'s (2008) scale to measure four drivers of service value. This consists of three drivers of customer perceived benefits: four items for service quality, four items for service equity, and five items for confidence benefits; and a driver of customer perceived sacrifices (three items) including price fairness, and service convenience. We believe this scale is well suited to our study, given its emphasis on perceived service value. Furthermore, according to Martin et al. (2008), the scale can be generalized to other contexts (see Appendix 1).

\section{Results}

\section{Data analysis}

This study uses the partial least squares (PLS) method for data analysis. PLS is a structural equation modeling technique which employs a principal component-based estimation approach (Chin, 1998). PLS was selected due to the characteristics of our model and sample. As the model uses reflective and formative indicators and the data are non-normal, other software packages for structural equation modeling (e.g. LISREL or AMOS) were deemed inappropriate (Diamantopoulos and Winklhofer, 2001).

Using PLS involves a two-stage approach (Barclay et al., 1995). The first step requires the assessment of the measurement model. This allows the relationships between the observable variables and theoretical concepts to be specified. This analysis is performed in relation to the attributes of individual item reliability, construct reliability, average variance extracted (AVE), and discriminant validity of the indicators of latent variables. The structural model is then evaluated. The objective is to confirm the extent to which the causal relationships specified by the proposed model are consistent with the available data.

Understanding whether the underlying essence of the construct is reflective (changes in the underlying construct cause changes in the indicators) or formative 
(indicators impact or cause the underlying construct) is an essential first step in modeling its structure (Jarvis et al., 2003; MacKenzie et al., 2005). There are some issues to address when defining a construct as reflective or formative. First, in reflective models, the causality direction moves from the construct to the items (or components), whereas in formative indicators, causality should move from measures to the construct (Diamantopoulos and Winklhofer, 2001). Second, indicators in reflective models should be interchangeable (Jarvis et al., 2003). Third, with reflective measures, all components should covary with one another (Jarvis et al., 2003; MacKenzie et al., 2005). To analyze the relationships between the different constructs and their indicators, we adopted the latent model perspective, in which the latent variable is understood to be the cause of the indicators and, therefore, we refer to reflective indicators for first-order constructs or dimensions. According to MacKenzie et al. (2005), the distinction between reflective and formative indicator models generalizes to higher-order factor structures. For many constructs conceptualized at a more abstract second-order level, multiple first-order subdimensions serve as reflective or formative indicators.

There are two reflective constructs in the model (knowledge storage/transfer, and knowledge application), while three constructs (PACAP, RACAP, and service value) are modeled as second-order formative constructs. With regard to the measurement model, we first assessed the individual item reliability (Table 1). All the indicators exceed the accepted threshold of 0.7 for each factor loading (Carmines and Zeller, 1979).

\section{Insert Table 1 about here}

According to the results shown in Table 2, we can say that the constructs are reliable. The values for both the Cronbach's alpha coefficient and composite reliability are above the threshold of 0.7 required in the early stages of research and the stricter value of 0.8 
for basic research (Nunnally, 1978). The study assesses convergent validity using the AVE. The value of AVE for all the constructs of our model exceeds 0.5 (Table 2), meaning that $50 \%$ or more variance of the indicators should be accounted for (Fornell and Larcker, 1981). The study examines discriminant validity using a correlation matrix. To assess the discriminant validity of the constructs, we compared the square root of the AVE (the diagonal in Table 2) with the correlations between constructs (the off-diagonal elements in Table 2). On average, each construct relates more strongly to its own measures than to others. Hence, discriminant validity is satisfactory.

Table 2 also summarizes the means, standard deviations (SD), correlation coefficients, and AVE of the constructs in the study.

\section{Insert Table 2 about here}

The formative dimensions of the second-order constructs, PACAP and RACAP, are evaluated differently from reflective ones. We need to examine the weights (Mathieson et al., 2001), which is a canonical correlation analysis and provides information about how each indicator contributes to its respective construct (see Table 3 ). The concern with regard to formative dimensions is the potential multicollinearity with overlapping dimensions, which could produce unstable estimates (Mathieson et al., 2001). Results of a collinearity test show that the variance inflation factor (VIF) scores of each secondorder construct for all dimensions are far below the commonly accepted cut-off of 3.3 (Diamantopoulos and Siguaw, 2006; Roberts and Thatcher, 2009).

\section{Insert Table 3 about here}

Consistent with Hair et al. (2011), a bootstrap test (5000 resamples) was used to generate standard errors and t-statistics. This enabled us to determine the significance of the path coefficients. Table 4 sets out the model statistics, the path coefficients and the t-values observed with the level of significance obtained from the bootstrap test. All the 
paths are significant. Finally, the standardized root mean square residual (SRMR) fit index of the model is 0.077 , below the proposed cut-off of 0.08 (Henseler et al., 2014; Hu and Bentler, 1999; Sarstedt et al., 2014).

\section{Insert Table 4 about here}

According to our results, we find support for all the hypotheses proposed in the model. Hypothesis 1 confirms that potential and realized absorptive knowledge capacities are different and sequential constructs that are directly related in a KM process.

In addition, hypothesis 2 shows the indirect linkage between those capacities, partially mediated by knowledge storage/transfer. Tests on the mediation hypothesis $\left(\mathrm{H}_{2}\right)$ use an application of the analytical approach that Hayes et al. (2011) describe. Figure 2A expresses the total effect of PACAP on RACAP as the sum of the direct (c) and indirect effect $(\mathrm{ab})$. The estimation of the indirect effect uses the product of the path coefficients in the meditational chain. Figure $2 \mathrm{~B}$ shows the total effect (c') of PACAP on RACAP.

\section{Please insert Figure 2 here}

According to Baron and Kenny (1986), knowledge storage/transfer is a mediator if: a) PACAP significantly accounts for variability in knowledge storage/transfer $(\beta=0.706$, $\mathrm{p}<0.001$ ), b) knowledge storage/transfer significantly accounts for variability in RACAP when controlling for PACAP $(\beta=0.534, \mathrm{p}<0.001)$, c) PACAP significantly accounts for variability in RACAP $(\beta=0.438, \mathrm{p}<0.001)$ and $\mathrm{d})$ the effect of PACAP on RACAP decreases substantially when knowledge storage/transfer is entered simultaneously with PACAP as a predictor of $\operatorname{RACAP}(\beta=0.815, \mathrm{p}<0.001$ vs $\beta=0.438$, $\mathrm{p}<0.001$ ). Considered together, these points provide evidence that there is a partial mediating effect of knowledge storage/transfer and that the partial mediation model 
represents a significant improvement over the total effect model (Baron and Kenny, 1986; Mathieu and Taylor, 2006).

The application of bootstrapping also allows for testing of the mediation hypothesis (Chin, 2010; Preacher and Hayes, 2008). This study's 5000 resamples generate $95 \%$ confidence intervals (percentile) for the mediator. If the interval for a mediation hypothesis does not contain zero, it means that the indirect effect is significantly different from zero with $95 \%$ confidence. As Figure $2 \mathrm{~B}$ and Table 5 show, PACAP has a significant total effect on RACAP $\left(c^{\prime}=0.815 ; \mathrm{p}<0.001\right)$. When adding the mediator (Figure 2A), PACAP decreases its influence, but maintains a significant direct effect on RACAP $(\mathrm{c}=0.438, \mathrm{p}<0.001)$. Therefore, these results support hypothesis 2 . Consequently, Table 5 shows that knowledge storage/transfer partially mediate the relationship between PACAP and RACAP.

\section{Insert Table 5 about here}

The variance accounted for (VAF) determines the size of the indirect effect in relation to the total effect (Hair et al., 2014). In our case, VAF is 0.45 . According to Hair et al. (2014), a situation in which the VAF is larger than $20 \%$ and less than $80 \%$ can be characterized as partial mediation.

In hypothesis 3 the authors explore the relationship between realized knowledge and its application within the service company, which implies the use of the knowledge generated in the previous phases of knowledge creation and retained in the phase of storage/transfer. Our results show there is a strong link between these constructs.

Finally, KM processes must ultimately be reflected in the customer in order to become a competitive advantage. We test the relationship between knowledge application and service value creation, differentiating between benefits and sacrifices in hypotheses 4.1 and 4.2. As we expected, service firms that are able to apply more 
knowledge or apply knowledge more effectively are likely to generate more benefits for their customers, and/or reduce their sacrifices, contributing significantly to a higher customer perception of service value.

\section{Discussion}

\section{Theoretical implications}

Traditionally, value research has been focused on the evaluation of how firms create value for their customers and how customers perceive the superior value of what the firm is offering (Martelo-Landroguez et al., 2013). In this context, we believe that KM must be considered as a framework for designing firms' goals, structures and processes in order to create value for their customers (Vorakulpipat and Rezgui, 2008). Therefore, the aim of firms that manage their knowledge is the creation of superior service value. However, a firm only truly creates value when the customer perceives that value. Consequently, service value creation should be guided by the value perceived by the customers.

The purpose of this study is to examine the relationship between the different processes of KM and the potential effects of this relationship on the creation of service value. The specific research question is how service firms should manage their knowledge in order to enhance the delivery of service value to customers. A key asset of our research is that we tested our model following a multi-informant approach (linking the internal perceptions of managers with the external perceptions of customers). According to the results of this research, we found a relationship between KM processes and service value, which has been acknowledged as a major source of competitive advantage. Our findings show that knowledge should first be acquired and assimilated by service firms, then stored before being transformed and exploited; finally, it should be used in order to increase the customer's perception of service value. 
Our model has four hypotheses. Initially, the organization's RACAP is both directly and indirectly influenced by PACAP, through the means of knowledge storage/transfer of bank employees $\left(\mathrm{H}_{1}\right.$ and $\left.\mathrm{H}_{2}\right)$. The results of the mediation effect analysis are consistent with the hypothesis of a partially mediated effect. Therefore, we confirm that the influence of PACAP on RACAP is partially mediated by knowledge storage and transfer in service firms.

Next, hypothesis $\mathrm{H}_{3}$ confirms the relationship between RACAP and knowledge application. A conclusion of this result is that firms need to know how knowledge is created, shared and used so it can be successfully applied to specific situations. This is especially relevant in the case of services, which are directed at intangible assets - such as banking - where the core of the service relies on information and knowledge. Therefore, those service firms that can identify, evaluate, create and develop their knowledge resources would be in a position of advantage. A knowledge environment should allow identification, capture and retrieval of relevant knowledge, while promoting the social activities that underpin the knowledge sharing and creation process. Knowledge-based service firms need their employees to be part of a culture that promotes the virtues of the different KM processes.

In the second group of hypotheses $\left(\mathrm{H}_{4.1}\right.$ and $\left.\mathrm{H}_{4.2}\right)$, this paper offers empirical evidence of the need to improve the delivery of service value to customers through the management of knowledge both from inside and outside the firm. By paying attention to the key process of KM, the service firm will increase customers' perceived benefits and decrease customers' perceived sacrifices of service value. Thus, the application of knowledge should be a driver of service value creation in service firms in order to achieve a competitive advantage. Our results confirm that the correct application of knowledge leads to the delivery of superior value to customers, although this 
relationship is stronger through the enhancing of service benefits (i.e. service quality, service equity, and confidence benefits) than through the reduction of any sacrifices (i.e. prices, time, and effort). In other words, our results suggest that service companies who apply their knowledge better than their competitors are likely to generate enhanced service quality, customer's trust, and customer's preference for its services.

It is well acknowledged that knowledge resources are the main determinants of superior performance as they are VRIN resources that lead to a sustained competitive advantage. As mentioned before, resources must be valuable, rare, inimitable, and nonsubstitutable (VRIN) to serve as a basis for sustained competitive advantages. Such an idea encompasses a service orientation that will have an impact on customer perception of service value, and therefore, on their behavior. The increasingly important role of service value in customers' purchasing and repurchasing decisions is forcing firms to seek new ways of creating service value. Indeed, the customer makes evaluations based on service value, and therefore on the comparison between the benefits and sacrifices of a given value proposal. Our research has confirmed that there is a positive link between KM processes and customer perceptions of value, providing support for this theoretical background.

\section{Managerial implications in the banking industry}

Here, we highlight managerial implications that have evolved from the results. Knowledge application is directly related to the customer's perceived benefits and sacrifices. The source of competitive advantages resides in the application of knowledge rather than in the knowledge itself. Thus, service firms (i.e. banks) need to know how to increase knowledge application in order to increase the delivery of service value to customers. According to our study, if banks want to improve the application of 
knowledge, it is important to focus on knowledge retention while they create new knowledge.

For example, best customer relationship management practices require the gathering and storing of information related to the actual and potential profitability of customers. Front-line employees are in the right position to put this information into the system, generating customer knowledge that can lead to a competitive advantage when it is properly managed.

As mentioned previously, banking companies must deliver the right service at the right time to the right customer. Knowledge sharing individually and collectively by banking staff is vital. Decisions based on past experiences may not be the most appropriate ones, so there is a need to know-how, know-what, know-where, and knowwhy to respond to market demands.

For banks, it is also important to apply that knowledge; that is, to use their stored information wisely. Banks must take into account that storing the right information is one thing whereas knowledge application, and how to utilize it properly, is quite another.

Consequently, if banks carry out these three key KM processes in the order given in Figure 1, customer benefits will increase and customer sacrifices will decrease. More precisely, our results show that the application of knowledge will help to achieve higher levels of service quality. Service quality has many attributes that can be drawn from such knowledge, such as competence, reliability, empathy, and the ability of the service provider to deliver consistently satisfactory experiences for the customer. These aspects are not easy to imitate and are rooted in knowledge capabilities. In addition, service equity contributes to the reduction of uncertainty, which is extremely important when customer levels of trust in the banking industry are very low. Generating trust, 
reducing risks, and avoiding opportunism are essential drivers of value creation in banking services. Finally, a knowledge-based company must know who are its best customers and treat them accordingly. This can be done by reducing any sacrifices to them, providing better prices, saving time and trouble, and reducing any issues in the service banking operations.

\section{Limitations of the study and future research}

All the findings of this study must be cautiously accepted, considering the following limitations - even though it is possible that limitations can lead to new areas of future development.

First, the application of knowledge explains a low percentage of variance of customer perceived benefits $\left(\mathrm{R}^{2}=0.016\right)$ and sacrifices $\left(\mathrm{R}^{2}=0.004\right)$, although the relationships are significant and in the same direction as was expected - knowledge application enhances customer benefits and reduces customer sacrifices. This result suggests there may be "something else" between the customer perceptions and the firm's KM processes. Customer-contact employees link both ends: they deliver the service in the eyes of the customer and they are also responsible of proper implementation of the service company's strategies. We speculate that including frontline employees' related variables would increase the explanatory power of the model, opening up interesting areas for research in the topic. For instance, we could examine how KM practices affect the employee-customer interface in service companies.

Second, the study focuses on one particular industry (the Spanish banking industry). A variety of service industries would help to generalize our findings. Although the application of KM does not really differ from other service industries rooted in information, it is true that the banking environment is extremely complex (and 
especially suited to the conducting of a KM study). In addition, KM is developing very fast in the banking industry (Ugurlu and Kizildag, 2013), so another limitation of the study is that the scores of the constructs may vary in time, and longitudinal studies may help establish the causality of the relationships (something which we, using crosssectional data, cannot easily assess).

It could also be useful to consider the findings from this study in conjunction with the emerging body of literature on the microfoundations of dynamic capabilities. While much progress has been made in studying capabilities such as KM, the underlying microfoundations or origins of these constructs have not received adequate attention (Felin et al., 2012; Hodgkinson and Healey, 2011; Teece, 2007). Does KM let service firms to develop competitive advantages in rapidly changing environments? Does KM processes impact service firms in the same way in these volatile environments? Thus, could we consider $\mathrm{KM}$ as a microfoundation of dynamic capabilities in service firms? This is worthy of further investigation and could constitute an interesting topic for future research. 


\section{References}

Agarwal, S. and Teas, R.K. (2001), "Perceived value: mediating role of perceived risk", Journal of Marketing Theory and Practice, Vol. 9 No. 4, pp. 1-14.

Alavi, M. and Leidner, D.E. (2001), "Review: Knowledge management and knowledge management systems: conceptual foundations and research issues", MIS Quarterly, Vol. 25 No. 1, pp. 107-136.

Ali, H.M. and Ahmad, N.H. (2006), "Knowledge management in Malaysian banks: a new paradigm", Journal of Knowledge Management Practice, Vol. 7 No. 3, pp. 113.

Alrawi, K. and Elkhatib, S. (2009), "Knowledge management practices in the banking industry: present and future state - case study", Journal of Knowledge Management Practice, Vol. 10 No. 4, pp. 1-10.

Argote, L., Beckman, S.L. and Epple, D. (1990), "The persistence and transfer of learning in industrial settings", Management Science, Vol. 36, pp. 140-154.

Argote, L., McEvily, B. and Reagans, R. (2003), "Managing knowledge in organizations: an integrative framework and review of emerging themes", Management Science, Vol. 49, pp. 571-582.

Barclay, D., Higgins, C. and Thompson, R. (1995), “The partial least squares (PLS) approach to causal modelling: personal computer adoption and use as an illustration", Technology Studies, Vol. 2, pp. 285-309.

Barney, J.B. (1991), "Firm resources and sustained competitive advantage", Journal of Management, Vol. 17, pp. 99-120.

Baron, R.M. and Kenny, D.A. (1986), “The moderator-mediator variable distinction in social psychological research: conceptual, strategic, and statistical considerations", Journal of Personality and Social Psychology, Vol. 51 No. 6, pp. 1173-1182.

Baskerville, R. and Dulipovici, A. (2006), "The theoretical foundations of knowledge management”, Knowledge Management Research \& Practice, Vol. 4, pp. 83-105.

Bhatt, G.D. (2001), "Knowledge management in organizations: examining the interaction between technologies, techniques, and people”, Journal of Knowledge Management, Vol. 5, pp. 68-75.

Blattberg, R.C., Getz, G. and Thomas, J.S. (2001), Customer Equity: Building and Managing Relationships as Valuable Assets, Harvard Business School Press, Boston, MA. 
Boksberger, P.E. and Melsen, L. (2011), "Perceived value: a critical examination of definitions, concepts and measures for the service industry", Journal of Services Marketing, Vol. 25, pp. 229-240.

Bowen, J. (1990), "Development of a taxonomy of services to gain strategic marketing insights", Journal of the Academy of Marketing Science, Vol. 18 No. 1, pp. 43-49.

Brown, J.S. and Duguid, P. (2001), "Knowledge and organization: a social-practice perspective", Organization Science, Vol. 12, pp. 198-213.

Carbó, S., Pedauga, L.E. and Rodríguez, F. (2011), "La reordenación bancaria española: efectos sobre la estructura de mercado", Papeles de Economía Española, Vol. 130, pp. 217-229.

Carmines, E.G. and Zeller, R.A. (1979), Reliability and Validity Assessment, Sage, London.

Cengiz, E. and Kirkbir, F. (2007), "Customer perceived value: the development of a multiple item scale in hospitals", Problems \& Perspectives in Management, Vol. 5 No. 3, pp. 252-268.

Chang Lee, K., Lee, S. and Kang, I.W. (2005), "KMPI: measuring knowledge management performance", Information \& Management, Vol. 42, pp. 469-482.

Chaston, I. (2012), "Entrepreneurship and knowledge management in small servicesector firms", The Service Industries Journal, Vol. 32, pp. 845-860.

Chen, C.-J. and Huang, J.-W. (2009), "Strategic human resource practices and innovation performance - The mediating role of knowledge management capacity", Journal of Business Research, Vol. 62, pp. 104-114.

Chin, W.W. (1998), "Issues and opinion on structural equation modeling", MIS Quarterly, Vol. 22 No. 1, pp. 1-12.

Chin, W.W. (2010), "How to write up and report PLS analyses", in Vinzi, V.E., Chin, W.W., Henseler, J.O. and Wang, H. (Eds.), Handbook of Partial Least Squares, Springer Handbooks of Computational Statistics, Springer-Verlag, Berlin.

Chou, S.-W. (2005), "Knowledge creation: absorptive capacity, organizational mechanisms, and knowledge storage/retrieval capabilities", Journal of Information Science, Vol. 31, pp. 453-465.

Chou, T.-C., Chang, P.-L., Cheng, Y.-P. and Tsai, C.-T. (2007), “A path model linking organizational knowledge attributes, information processing capabilities, and perceived usability", Information \& Management, Vol. 44, pp. 408-417. 
Cohen, W.M. and Levinthal, D.A. (1990), “Absorptive capacity: a new perspective on learning and innovation", Administrative Science Quarterly, Vol. 35, pp. 128-152.

Cronin, J.J., Brady, M.K. and Hult, G.T.M. (2000), “Assessing the effects of quality, value, and customer satisfaction on consumer behavioral intentions in service environments", Journal of Retailing, Vol. 76, pp. 193-218.

Cui, A.S., Griffith, D.A. and Cavusgil, S.T. (2005), "The influence of competitive intensity and market dynamism on knowledge management capabilities of multinational corporation subsidiaries", Journal of International Marketing, Vol. 13 No. 3, pp. 32-53.

Darr, E.D., Argote, L. and Epple, D. (1995), “The acquisition, transfer and depreciation of knowledge in service organizations: productivity in franchises", Management Science, Vol. 41 No. 11, pp. 1750-1762.

Davenport, T.H. and Prusak, L. (1998), Working Knowledge, Harvard Business School Press, Boston, MA.

De Vries, R.E., Van den Hooff, B. and De Ridder, J.A. (2006), "Explaining knowledge sharing: the role of team communication styles, job satisfaction, and performance beliefs", Communication Research, Vol. 33 No. 2, pp. 115-135.

Demarest, M. (1997), “Understanding knowledge management”, Long Range Planning, Vol. 30 No. 3, pp. 374-384.

Diamantopoulos, A. and Siguaw, J.A. (2006), "Formative versus reflective indicators in organizational measure development: a comparison and empirical illustration", British Journal of Management, Vol. 17 No. 4, pp. 263-282.

Diamantopoulos, A. and Winklhofer, H. (2001), "Index construction with formative indicators: an alternative to scale development", Journal of Marketing Research, Vol. 38 No. 2, pp. 269-277.

Du, R.Y., Kamakura, W.A. and Mela, C.F. (2007), "Size and share of customer wallet", Journal of Marketing, Vol. 71 No. 2, pp. 94-113.

Earl, M. (2001), "Knowledge management strategies: toward a taxonomy”, Journal of Management Information Systems, Vol. 18 No. 1, pp. 215-233.

Edvardsson, I.R. and Oskarsson, G.K. (2011), "Knowledge management and value creation in service firms", Measuring Business Excellence, Vol. 15 No. 4, pp. 7-15.

Felin, T., Foss, N.J., Heimeriks, K.H. and Madsen, T.L. (2012), "Microfoundations of routines and capabilities: individuals, processes, and structure", Journal of Management Studies, Vol. 49, pp. 1351-1374. 
Fornell, C. and Larcker, D.F. (1981), "Evaluating structural equation models with unobservable variables and measurement error", Journal of Marketing Research, Vol. 18, pp. 39-50.

Gebauer, H., Johnson, M. and Enquist, B. (2010), "Value co-creation as a determinant of success in public transport services: a study of the Swiss Federal Railway operator (SBB)”, Managing Service Quality, Vol. 20 No. 6, pp. 511-530.

Gebert, H., Geib, M., Kolbe, L. and Brenner, W. (2003), “Knowledge-enabled customer relationship management: integrating customer relationship management and knowledge management concepts[1]", Journal of Knowledge Management, Vol. 7 No. 5, pp. 107-123.

Gold, A.H., Malhotra, A. and Segars, A.H. (2001), "Knowledge management: an organizational capabilities perspective", Journal of Management Information Systems, Vol. 18 No. 1, pp. 185-214.

Grant, R.M. (1996), "Toward a knowledge-based theory of the firm", Strategic Management Journal, Vol. 17, pp. 109-122.

Grönroos, C. and Ravald, A. (2011), "Service as business logic: implications for value creation and marketing”, Journal of Service Management, Vol. 22 No. 1, pp. 5-22.

Grover, V. and Davenport, T.H. (2001), "General perspectives on knowledge management: fostering a research agenda", Journal of Management Information Systems, Vol. 18 No. 1, pp. 5-21.

Hair, J.F., Hult, G.T., Ringle, C.M. and Sarstedt, M. (2014), A Primer on Partial Least Squares Structural Equation Modeling (PLS-SEM), Sage Publications, Thousand Oaks, CA.

Hair, J.F., Ringle, C.M. and Sarstedt, M. (2011), "PLS-SEM: indeed a silver bullet", Journal of Marketing Theory and Practice, Vol. 19 No. 2, pp. 139-152.

Hayes, A.F., Preacher, K.J. and Myers, T.A. (2011), "Mediation and the estimation of indirect effects in political communication research", in Bucy, E.P. and Holbert, R.L. (Eds.), Sourcebook for Political Communication Research: Methods, Measures, and Analytical Techniques, Routledge, New York, pp. 434-465.

Henseler, J., Dijkstra, T.K., Sarstedt, M., Ringle, C.M., Diamantopoulos, A., Straub, D.W., Ketchen, D.J., Hair, J.F., Hult, G.T.M. and Calantone, R.J. (2014), “Common beliefs and reality about PLS: comments on Rönkkö \& Evermann”, Organizational Research Methods, Vol. 17 No. 2, pp. 182-209. 
Hodgkinson, G.P. and Healey, M.P. (2011), "Psychological foundations of dynamic capabilities: reflexion and reflection in strategic management", Strategic Management Journal, Vol. 32, pp. 1500-1516.

Homburg, C., Wieseke, J. and Bornemann, T. (2009), "Implementing the marketing concept at the employee-customer interface: the role of customer need knowledge", Journal of Marketing, Vol. 73 No. 4, pp. 64-81.

Hu, L.-T. and Bentler, P.M. (1999), "Cutoff criteria for fit indexes in covariance structure analysis: conventional criteria versus new alternatives", Structural Equation Modeling: A Multidisciplinary Journal, Vol. 6 No. 1, pp. 1-55.

Hu, T.-S., Lin, C.-Y. and Chang, S.-L. (2013), "Knowledge intensive business services and client innovation", The Service Industries Journal, Vol. 33, pp. 1435-1455.

Huang, J.-W. and Li, Y.-H. (2009), “The mediating effect of knowledge management on social interaction and innovation performance", International Journal of Manpower, Vol. 30 No. 3, pp. 285-301.

Iniesta-Bonillo, M.A., Sánchez-Fernandez, R. and Cervera-Taulet, A. (2012), “Online value creation in small service businesses: the importance of experience valence and personal values", The Service Industries Journal, Vol. 32, pp. 2445-2462.

Ipe, M. (2003), "Knowledge sharing on organizations: a conceptual framework", Human Resource Development Review, Vol. 2 No. 4, pp. 337-359.

Jansen, J.J.P., Van den Bosch, F.A.J. and Volberda, H.W. (2005), "Managing potential and realized absorptive capacity: how do organizational antecedents matter?", Academy of Management Journal, Vol. 48 No. 6, pp. 999-1015.

Jantunen, A. (2005), "Knowledge-processing capabilities and innovative performance: an empirical study", European Journal of Innovation Management, Vol. 8 No. 3, pp. 336-349.

Jarvis, C.B., MacKenzie, S.B. and Podsakoff, P.M. (2003), “A critical review of construct indicators and measurement model misspecification in marketing and consumer research”, Journal of Consumer Research, Vol. 30 No. 2, pp. 199-218.

Jayasundara, C.C. (2008), "Knowledge management in banking industries: uses and opportunities”, Journal of the University Librarians Association of Sri Lanka, Vol. 12 , pp. 68-84.

Kaplan, R.S. and Norton, D.P. (2004), “The strategy map: guide to aligning intangible assets”, Strategy \& Leadership, Vol. 32 No. 5, pp. 10-17. 
Lages, C.R., Simões, C.M.N., Fisk, R.P. and Kunz, W.H. (2013), "Knowledge dissemination in the global service marketing community", Managing Service Quality, Vol. 23 No. 4, pp. 272-290.

Lam, S.Y., Shankar, V., Erramilli, M.K. and Murthy, B. (2004), "Customer value, satisfaction, loyalty, and switching costs: an illustration from a business-to-business service context", Journal of the Academy of Marketing Science, Vol. 32 No. 3, pp. 293-311.

Lara, F., Palacios-Marques, D. and Devece, C.A. (2012), "How to improve organisational results through knowledge management in knowledge-intensive business services", The Service Industries Journal, Vol. 32, pp. 1853-1863.

Lavergne, R. and Earl, R.L. (2006), "Knowledge management: a value creation perspective", Journal of Organizational Culture, Communication and Conflict, Vol. 10 No. 2, pp. 43-60.

Liao, S.-H., Wu, C.-C., Hu, D.-C. and Tsui, K.-A. (2010), "Relationships between knowledge acquisition, absorptive capacity and innovation capability: an empirical study on Taiwan's financial and manufacturing industries", Journal of Information Science, Vol. 36 No. 1, pp. 19-35.

Lin, H.-F. (2007), "A stage model of knowledge management: an empirical investigation of process and effectiveness", Journal of Information Science, Vol. 33 No. 6, pp. 643-659.

Lin, H.-F. and Lee, G.-G. (2005), "Impact of organizational learning and knowledge management factors on e-business adoption", Management Decision, Vol. 43 No. 2, pp. 171-188.

MacKenzie, S.B., Podsakoff, P.M. and Jarvis, C.B. (2005), "The problem of measurement model misspecification in behavioral and organizational research and some recommended solutions", Journal of Applied Psychology, Vol. 90 No. 4, pp. 710-730.

Mahoney, J.T. and Pandian, J.R. (1992), "The resource-based view within the conversation of strategic management", Strategic Management Journal, Vol. 13 No. 5, pp. 363-380.

Malhotra, N.K. and Birks, D.F. (2006), Marketing Research, an Applied Approach, Updated Secondary European Edition, Pearson Education, Harlow, UK. 
Martelo-Landroguez, S., Barroso-Castro, C. and Cepeda, G. (2013), "Developing an integrated vision of customer value", Journal of Services Marketing, Vol. 27 No. 3, pp. 234-244.

Martin, D., Gremler, D.D., Washburn, J.H. and Cepeda, G. (2008), "Service value revisited: specifying a higher-order, formative measure", Journal of Business Research, Vol. 61 No. 12, pp. 1278-1291.

Mathieson, K., Peacock, E. and Chin, W.W. (2001), "Extending the technology acceptance model: the influence of perceived user resources", Database for Advances in Information Systems, Vol. 32 No. 3, pp. 86-112.

Mathieu, J.E. and Taylor, S.R. (2006), "Clarifying conditions and decision points for mediational type inferences in organizational behavior", Journal of Organizational Behavior, Vol. 27 No. 8, pp. 1031-1056.

McAdam, R. and McCreedy, S. (1999), “A critical review of knowledge management models", The Learning Organization, Vol. 6 No. 3, pp. 91-100.

McDonald, R.E. and Madhavaram, S. (2007), "What firms learn depends on what firms know: the implications of prior knowledge for market orientation", Marketing Management Journal, Vol. 17 No. 1, pp. 171-183.

Mohsen, Z.A., Ali, M. and Jalal, A. (2011), "The significance of knowledge management systems at financial decision making process", International Journal of Business and Management, Vol. 6 No. 8, pp. 130-142.

Monroe, K.B. (1990), Pricing- Making Profitable Decisions, McGraw-Hill, London.

Mustak, M., Jaakkola, E. and Halinen, A. (2013), "Customer participation and value creation: a systematic review and research implications", Managing Service Quality, Vol. 23 No. 4, pp. 341-359.

Nilakanta, S., Miller, L.L. and Zhu, D. (2006), “Organizational memory management: technological and research issues", Journal of Database Management, Vol. 17 No. 1, pp. 85-94.

Nunnally, J.C. (1978), Psychometric Theory, McGraw-Hill, New York, NY.

O’Dell, C. and Grayson, C.J. (1998), "If only we knew what we know: identification and transfer of internal best practices”, California Management Review, Vol. 40 No. 3, pp. 154-174.

Osterloh, M. and Frey, B.S. (2000), "Motivation, knowledge transfer, and organizational forms", Organization Science, Vol. 11 No. 5, pp. 538-550. 
Payne, A. and Holt, S. (2001), "Diagnosing customer value: integrating the value process and relationship marketing”, British Journal of Management, Vol. 12 No. 2, pp. 159-182.

Peteraf, M.A. (1993), “The cornerstones of competitive advantage: a resource-based view”, Strategic Management Journal, Vol. 14 No. 3, pp. 179-191.

Porter, M.E. (1985), Competitive Advantage - Creating and Sustaining Superior Performance, Free Press, New York, NY.

Preacher, K.J. and Hayes, A.F. (2008), "Asymptotic and resampling strategies for assessing and comparing indirect effects in multiple mediator models", Behavior Research Methods, Vol. 40, pp. 879-891.

Rezgui, Y. (2007), “Knowledge systems and value creation”, Industrial Management \& Data Systems, Vol. 107 No. 2, pp. 166-182.

Ritala, P., Hyötylä, M., Blomqvist, K. and Kosonen, M. (2013), “Key capabilities in knowledge-intensive service business", The Service Industries Journal, Vol. 33, pp. 486-500.

Roberts, N. and Thatcher, J.B. (2009), "Conceptualizing and testing formative constructs: tutorial and annotated example", The Data Base for Advances in Information Systems, Vol. 40 No. 3, pp. 9-39.

Rust, R.T., Lemon, K.N. and Zeithaml, V.A. (2004), "Return on marketing: using customer equity to focus marketing strategy", Journal of Marketing, Vol. 68 No. 1, pp. 109-127.

Sánchez, R. and Iniesta, M.A. (2006), “Consumer perception of value: literature review and a new conceptual framework", Journal of Consumer Satisfaction, Dissatisfaction and Complaining Behavior, Vol. 19, pp. 40-48.

Sánchez, R., Iniesta, M.A. and Holbrook, M.B. (2009), "The conceptualisation and measurement of consumer value in services", International Journal of Market Research, Vol. 51 No. 1, pp. 93-113.

Sarstedt, M., Ringle, C.M., Henseler, J. and Hair, J.F. (2014), "On the emancipation of PLS-SEM: a commentary on Rigdon (2012)”, Long Range Planning, Vol. 47 No. 3, pp. 154-160.

Singh, J. and Sidershmukh, D. (2000), "Agency and trust mechanisms in consumer satisfaction and loyalty judgements", Journal of the Academy of Marketing Science, Vol. 28 No. 1, pp. 150-167. 
Smith, J.B. and Colgate, M. (2007), "Customer value creation: a practical framework", Journal of Marketing Theory \& Practice, Vol. 15 No. 1, pp. 7-23.

Spender, J.C. (2006), "Getting value from knowledge management", The TQM Magazine, Vol. 18 No. 3, pp. 238-254.

Spender, J.C. and Scherer, A.G. (2007), “The philosophical foundations of knowledge management: editors’ introduction”, Organization, Vol. 14 No. 1, pp. 5-28.

Storey, C. and Hull, F.M. (2010), "Service development success: a contingent approach by knowledge strategy", Journal of Service Management, Vol. 21 No. 2, pp. 140161.

Teece, D.J. (2007), "Explicating dynamic capabilities: the nature and microfoundations of (sustainable) enterprise performance", Strategic Management Journal, Vol. 28, pp. 1319-1350.

Ugurlu, Ö.Y. and Kizildag, D. (2013), “A comparative analysis of knowledge management in banking sector: an empirical research", European Journal of Business \& Management, Vol. 5 No. 16, pp. 12-19.

Vorakulpipat, C. and Rezgui, Y. (2008), "Value creation: the future of knowledge management”, The Knowledge Engineering Review, Vol. 23 No. 3, pp. 283-294.

Walsh, J.P. and Ungson, G.R. (1991), "Organizational memory", Academy of Management Review, Vol. 16 No. 1, pp. 57-91.

Wang, Y., Lo, H.P. and Hui, Y.V. (2003), "The antecedents of service quality and product quality and their influences on bank reputation: evidence from the banking industry in China", Managing Service Quality, Vol. 13 No. 1, pp. 72-83.

Wang, Y., Lo, H.P., Chi, R. and Yang, Y. (2004), “An integrated framework for customer value and customer-relationship-management performance: a customerbased perspective from China", Managing Service Quality, Vol. 14 No. 2/3, pp. 169-182.

Woodruff, R.B. (1997), "Customer value: the next source for competitive advantage", Journal of the Academy of Marketing Science, Vol. 25 No. 2, pp. 139-153.

Zahra, S.A. and George, G. (2002), “Absorptive capacity: a review, reconceptualization, and extension”, Academy of Management Review, Vol. 27 No. 2, pp. 185-203.

Zott, C. (2003), "Dynamic capabilities and the emergence of intraindustry differential firm performance: insights from a simulation study", Strategic Management Journal, Vol. 24 No. 2, pp. 97-125. 


\section{Appendix 1. Questionnaire items}

KNOWLEDGE MANAGEMENT (1=strongly disagree and 7=strongly agree).

Potential Absorptive Capacity (PACAP)

Acquisition

ACQ_1: Our unit has frequent interactions with corporate headquarters to acquire new knowledge

ACQ_2: Employees of our unit regularly visit other branches

ACQ_3: We collect industry information through informal means (e.g. lunch with industry friends, talks with trade partners)

ACQ_5: Our unit periodically organizes special meetings with customers or third parties to acquire new knowledge

ACQ_6: Employees regularly approach third parties such as accountants, consultants, or tax consultants

Assimilation

ASS_1: We are slow to recognize shifts in our market (e.g. competition, regulation, demography) (reverse-coded)

ASS_2: New opportunities to serve our clients are quickly understood

ASS_3: We quickly analyze and interpret changing market demands

Realized Absorptive Capacity (RACAP)

Transformation

TRA_1: Our unit regularly considers the consequences of changing market demands in terms of new products and services

TRA_2: Employees record and store newly acquired knowledge for future reference

TRA_3: Our unit quickly recognizes the usefulness of new external knowledge to existing knowledge

TRA_6: Our unit periodically meets to discuss consequences of market trends and new product development

Exploitation

EXP_1: It is clearly understood how activities within our unit should be performed

EXP_4: We constantly consider how to better exploit knowledge

EXP_5: Our unit has difficulty implementing new products and services (reverse-coded)

EXP_6: Employees have a common language regarding our products and services 


\section{Knowledge storage and transfer (KST)}

KST_1: Organizational conversation keeps the lessons learned from service development history at the front of our minds

KST_2: We always audit unsuccessful service development endeavors and communicate the lessons learned

KST_3: We have specific mechanisms for sharing lessons learned in the service development process

KST_4: Formal routines exist to uncover faulty assumptions about the service development process

\section{Knowledge application (KA)}

KA_1: My organization has processes for applying knowledge learned from mistakes

KA_2: My organization has processes for applying knowledge learned from experience

KA_3: My organization has processes for using knowledge in the development of new services

KA_4: My organization has processes for using knowledge to solve problems

KA_5: My organization matches sources of knowledge to problems and challenges

KA_6: My organization uses knowledge to improve efficiency

KA_7: My organization uses knowledge to adjust strategic direction

KA_8: My organization makes knowledge accessible to those who need it

KA_9: My organization takes advantage of new knowledge

KA_10: My organization applies knowledge to critical competitive needs

SERVICE VALUE ( $1=$ strongly disagree and 7=strongly agree).

\section{Customer Perceived Benefits (SV1)}

Service Quality

SQ_1: In general, this bank's service is reliable and consistent

SQ_2: My experience with this bank is always excellent

SQ_3: I would say that this bank provides superior service

SQ_4: Overall, I think this bank provides good service

Service Equity

SE_1: It makes sense to engage this bank's services compared to others, even if they are the same

SE_2: Even if another bank offers the same service, I would still prefer this bank

SE_3: If another bank offers services as good as this bank's, I would still prefer this bank 
SE_4: If another bank is not different from this bank in any way, it still seems smarter to purchase this bank's services

Confidence Benefits

CB_1: I have more confidence the service will be performed correctly

CB_2: I have less anxiety when I buy/use the services of this bank

CB_3: I believe there is less risk that something will go wrong

CB_4: I know what to expect when I go to this bank.

CB_5: I feel I can trust this bank

Customer Perceived Sacrifices (SV2)

PS_1: The price charged for this bank's services is high

PS_2: The time required to receive this bank's services is high

PS_3: The effort I expend to receive this bank's services is high 
Figure 1. Proposed model.

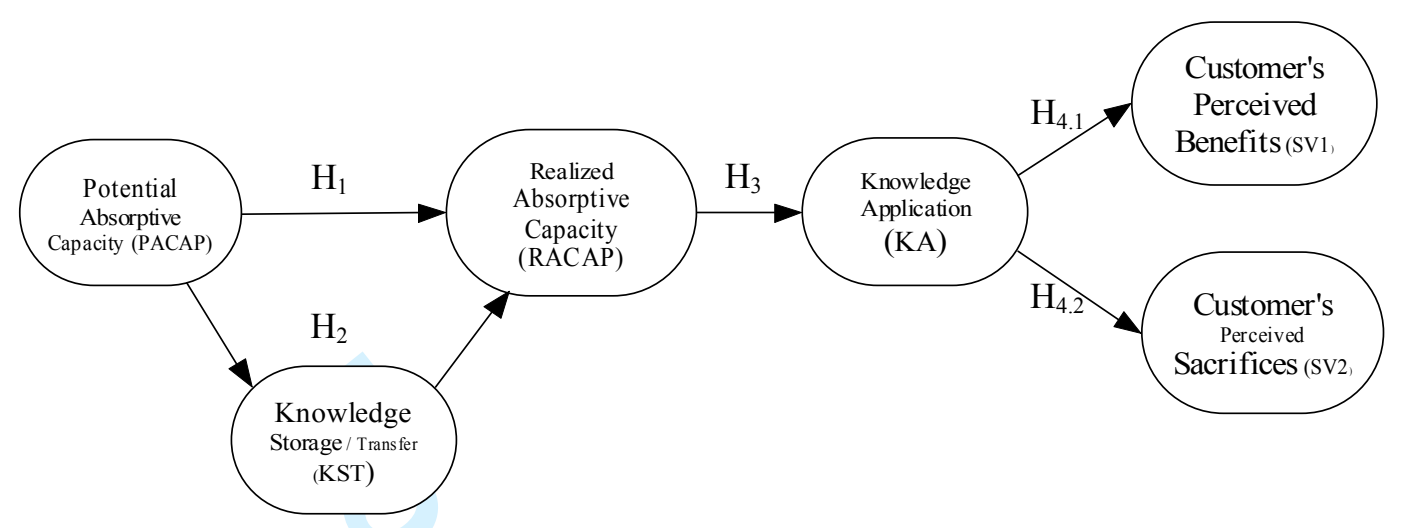


Figure 2. Mediation effect analysis.

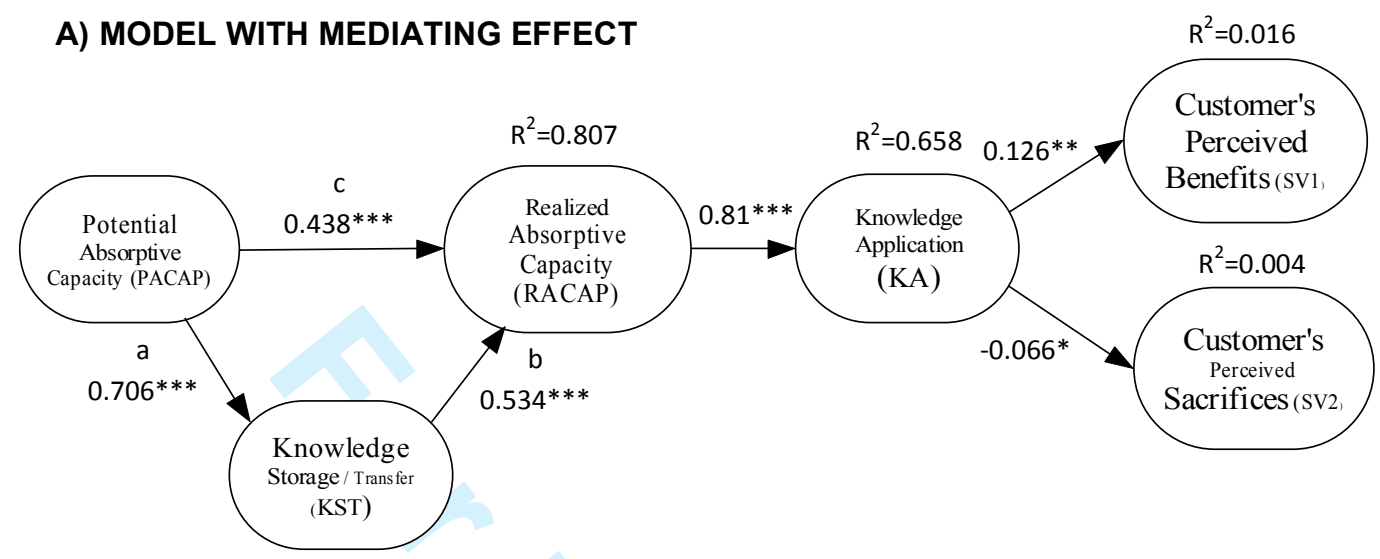

B) MODEL WITH TOTAL EFFECT

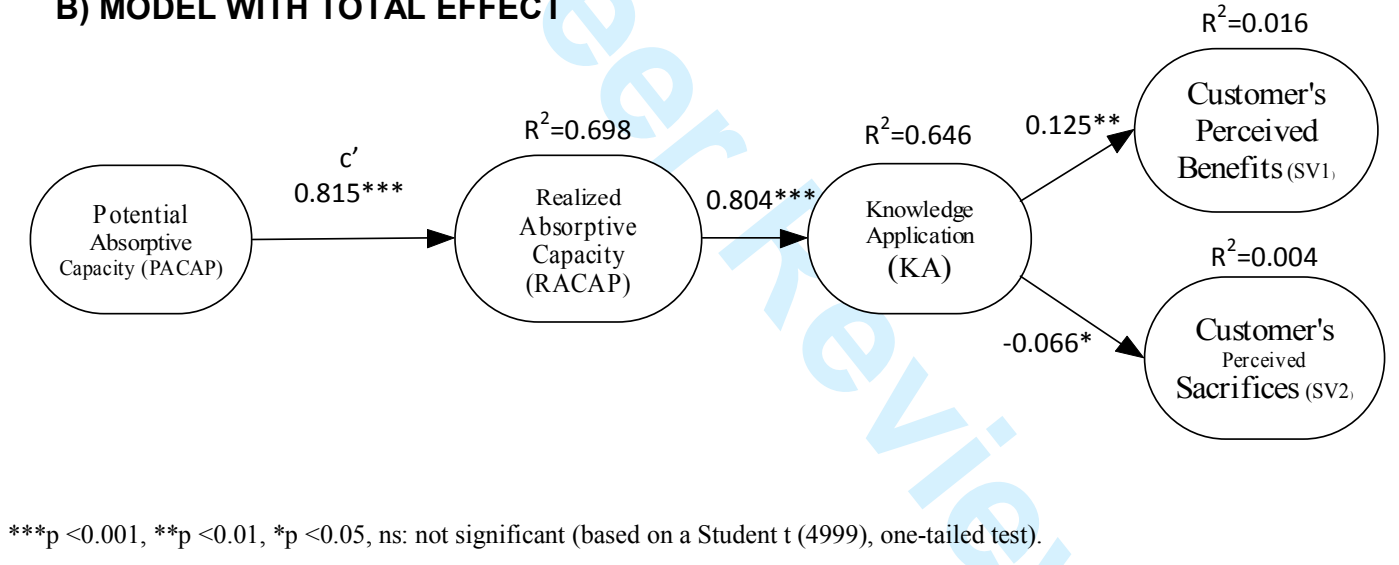


Table 1. Factor loadings for the measurement model.

\begin{tabular}{|c|c|c|c|c|c|c|c|c|c|}
\hline & Acquisition & Assimilation & Transformation & Exploitation & $\begin{array}{c}\text { Knowledge } \\
\text { Storage/Transfer }\end{array}$ & $\begin{array}{l}\text { Knowledge } \\
\text { Application }\end{array}$ & $\begin{array}{c}\text { Service } \\
\text { Equity }\end{array}$ & $\begin{array}{l}\text { Service } \\
\text { Quality }\end{array}$ & $\begin{array}{c}\text { Confidence } \\
\text { Benefits }\end{array}$ \\
\hline$A C Q 1$ & 0.8182 & 0.4252 & 0.5846 & 0.5364 & 0.487 & 0.6501 & 0.0203 & 0.0158 & 0.1242 \\
\hline$A C Q 2$ & 0.693 & 0.1963 & 0.4744 & 0.2887 & 0.2973 & 0.3286 & 0.1671 & 0.1407 & 0.1406 \\
\hline$A C Q 3$ & 0.7641 & 0.1171 & 0.4824 & 0.3412 & 0.2827 & 0.3919 & -0.0834 & -0.1086 & -0.0532 \\
\hline$A C Q 5$ & 0.7598 & 0.3369 & 0.4972 & 0.53 & 0.4165 & 0.3991 & 0.0477 & 0.0321 & 0.0558 \\
\hline$A C Q 6$ & 0.7126 & 0.2352 & 0.4971 & 0.3833 & 0.3445 & 0.4229 & -0.0602 & -0.0426 & -0.0645 \\
\hline$A S S 1$ & 0.2388 & 0.7709 & 0.4532 & 0.3298 & 0.5084 & 0.4944 & 0.2903 & 0.1813 & 0.23 \\
\hline$A S S 2$ & 0.4334 & 0.9173 & 0.6243 & 0.6733 & 0.637 & 0.6349 & 0.1367 & 0.1024 & 0.12 \\
\hline$A S S 3$ & 0.2615 & 0.9113 & 0.5841 & 0.5196 & 0.546 & 0.5106 & 0.1541 & 0.1446 & 0.1076 \\
\hline TRAI & 0.5695 & 0.5006 & 0.7805 & 0.5067 & 0.5661 & 0.602 & -0.1797 & -0.1331 & -0.1283 \\
\hline TRA2 & 0.4201 & 0.3816 & 0.6991 & 0.5397 & 0.4943 & 0.4897 & 0.1201 & 0.2256 & 0.1922 \\
\hline TRA3 & 0.5125 & 0.5787 & 0.8134 & 0.5265 & 0.6719 & 0.5791 & 0.0683 & 0.1078 & 0.1412 \\
\hline TRA6 & 0.5198 & 0.4495 & 0.69 & 0.5772 & 0.5594 & 0.5031 & -0.0552 & 0.0103 & -0.0119 \\
\hline EXPI & 0.5089 & 0.5226 & 0.5944 & 0.8351 & 0.6238 & 0.5775 & 0.1123 & 0.1656 & 0.1754 \\
\hline EXP4 & 0.4461 & 0.4836 & 0.6106 & 0.8618 & 0.7135 & 0.6125 & 0.0538 & 0.0848 & 0.0968 \\
\hline EXP5 & 0.3919 & 0.4779 & 0.5291 & 0.7211 & 0.5419 & 0.5176 & -0.1119 & -0.0977 & -0.1086 \\
\hline EXP6 & 0.4493 & 0.4089 & 0.4943 & 0.6985 & 0.4356 & 0.4753 & -0.2483 & -0.1761 & -0.1926 \\
\hline KST1 & 0.4543 & 0.6584 & 0.6028 & 0.6751 & 0.8465 & 0.6876 & 0.1198 & 0.1767 & 0.1938 \\
\hline KST2 & 0.4 & 0.5146 & 0.6114 & 0.6657 & 0.8518 & 0.6311 & 0.1355 & 0.245 & 0.1849 \\
\hline KST3 & 0.5108 & 0.5278 & 0.6059 & 0.604 & 0.8743 & 0.6798 & 0.0158 & 0.0052 & 0.0508 \\
\hline KST4 & 0.3511 & 0.5371 & 0.624 & 0.6448 & 0.8717 & 0.6462 & -0.0085 & 0.0229 & 0.0105 \\
\hline$K A 1$ & 0.3843 & 0.3835 & 0.5413 & 0.5315 & 0.5176 & 0.7776 & -0.094 & -0.0897 & -0.0109 \\
\hline$K A 2$ & 0.4464 & 0.5659 & 0.6271 & 0.5848 & 0.5816 & 0.8487 & 0.0001 & -0.0042 & 0.0215 \\
\hline$K A 3$ & 0.5577 & 0.6026 & 0.5996 & 0.6536 & 0.6489 & 0.8981 & 0.0026 & -0.0152 & 0.0259 \\
\hline KA4 & 0.5649 & 0.6989 & 0.5966 & 0.6449 & 0.7045 & 0.8777 & 0.0644 & 0.0628 & 0.0892 \\
\hline KA5 & 0.3833 & 0.5287 & 0.5183 & 0.6589 & 0.5807 & 0.799 & 0.1441 & 0.1254 & 0.1578 \\
\hline KA6 & 0.5991 & 0.3871 & 0.5673 & 0.5745 & 0.5853 & 0.807 & 0.0312 & 0.067 & 0.0768 \\
\hline KA7 & 0.5747 & 0.4598 & 0.5753 & 0.4779 & 0.6064 & 0.7641 & 0.1241 & 0.0898 & 0.0855 \\
\hline KT9 & 0.3702 & 0.4653 & 0.5525 & 0.589 & 0.6454 & 0.7272 & 0.031 & 0.0557 & 0.1081 \\
\hline KA10 & 0.5031 & 0.5092 & 0.5525 & 0.6563 & 0.6947 & 0.8505 & 0.1858 & 0.2248 & 0.2343 \\
\hline
\end{tabular}


Table 2. Descriptive statistics and correlation matrix.

\begin{tabular}{|c|c|c|c|c|c|c|c|c|c|c|c|c|}
\hline & Mean $^{\mathrm{a}}$ & SD & $\mathrm{CA}$ & CR & AVE & 1 & 2 & 3 & 4 & 5 & 6 & 7 \\
\hline 1. PACAP & 5.01 & 1.27 & n.a & n.a & n.a & n.a & & & & & & \\
\hline 2. Monetary Sacrifice & 3.85 & 0.73 & n.a & n.a & n.a & -0.08 & n.a & & & & & \\
\hline 3. RACAP & 5.57 & 1.05 & n.a & n.a & n.a & 0.82 & 0.02 & n.a & & & & \\
\hline 4. Knowledge Application & 5.47 & 1.09 & 0.95 & 0.953 & 0.671 & 0.75 & -0.08 & 0.79 & 0.82 & & & \\
\hline 5. Non-monetary Sacrifice & 3.31 & 0.56 & n.a & n.a & n.a & 0.01 & 0.75 & 0.02 & -0.06 & n.a & & \\
\hline 6. Knowledge Storage/Transfer & 5.16 & 1.12 & 0.88 & 0.920 & 0.742 & 0.70 & -0.05 & 0.82 & 0.77 & -0.07 & 0.86 & \\
\hline 7. Customer Perceived Benefits & 5.32 & 0.43 & 0.95 & 0.949 & 0.861 & 0.12 & -0.51 & -0.01 & 0.06 & -0.63 & 0.11 & 0.93 \\
\hline
\end{tabular}

Notes:

${ }^{a}$ Mean $=$ the average score for all of the items included in this measure; $\mathrm{SD} .=$ Standard Deviation; $\mathrm{CA}=$ Cronbach's Alpha; $\mathrm{CR}=$ Composite Reliability; $\mathrm{AVE}=\mathrm{Average}$ Variance Extracted; $\mathrm{n} . \mathrm{a} .=$ not applicable. The bold numbers on the diagonal are the square root of the Average Variance Extracted. Off-diagonal elements are correlations among constructs. 
Table 3. Weights of formative constructs, correlations, and collinearity test.

\begin{tabular}{|c|c|c|c|c|c|c|c|}
\hline High-order constructs and their dimensions (level) & Weights & Student $\mathrm{t}$ & VIF & \multicolumn{4}{|c|}{ Correlations } \\
\hline Potential Absorptive Capacity (second-order) & & & & ACQ & ASS & TRA & EXP \\
\hline Acquisition (first-order) & 0.57 & 6.03 & - & 1 & & & \\
\hline Assimilation (first-order) & 0.63 & 7.21 & 1.727 & $0.34 * *$ & 1 & & \\
\hline \multicolumn{8}{|l|}{ Realized Absorptive Capacity (second-order) } \\
\hline Transformation (first-order) & 0.58 & 6.76 & 2.426 & $0.675^{* *}$ & $0.631 * *$ & 1 & \\
\hline Exploitation (first-order) & 0.49 & 5.37 & 2.206 & $0.561 * *$ & $0.581 * *$ & $0.721 * *$ & 1 \\
\hline
\end{tabular}

${ }^{* * *} \mathrm{p}<0.001, * * \mathrm{p}<0.01,{ }^{*} \mathrm{p}<0.05$, ns: not significant (based on a Student t (4999), one-tailed test) 
Table 4. Model statistics.

\begin{tabular}{lccc}
\multicolumn{1}{c}{ Hypotheses } & $\begin{array}{c}\text { Path } \\
\text { coefficients }\end{array}$ & t-values $^{\mathrm{a}}$ & Supported? \\
\hline $\mathrm{H}_{1}:$ PACAP $\rightarrow$ RACAP & $0.438^{* * *}$ & 12.92 & Yes \\
$\mathrm{H}_{2}:$ PACAP $\rightarrow$ Knowledge Storage/Transfer & $0.706^{* * *}$ & 37.89 & Yes \\
$\mathrm{H}_{2}:$ Knowledge Storage/Transfer $\rightarrow$ RACAP & $0.534^{* * *}$ & 16.29 & Yes \\
$\mathrm{H}_{3}: \mathrm{RACAP} \rightarrow$ Knowledge Application & $0.811^{* * *}$ & 61.36 & Yes \\
$\mathrm{H}_{4.1}:$ Knowledge Application $\rightarrow$ Customer Perceived Benefits & $0.126^{* *}$ & 2.83 & Yes \\
$\mathrm{H}_{4.2}:$ Knowledge Application $\rightarrow$ Customer Perceived Sacrifices & $-0.066^{*}$ & -1.98 & Partially \\
\hline${ }^{* * *} \mathrm{p}<0.001, * * \mathrm{p}<0.01, * \mathrm{p}<0.05$, ns: not significant $($ based on a Student $\mathrm{t}(4999)$, one-tailed test). & \\
$\mathrm{t}(0.05,4999)=1.645158499, \mathrm{t}(0.01,4999)=2.327094067, \mathrm{t}(0.001,4999)=3.091863446$ & & \\
${ }^{\mathrm{a}}$ Factor correction applied. & &
\end{tabular}


Table 5. Summary of mediating effect test.

\begin{tabular}{|c|c|c|c|c|c|c|c|c|}
\hline \multicolumn{2}{|c|}{$\begin{array}{c}\text { Total effect of PACAP } \\
\text { on RACAP (c') }\end{array}$} & \multicolumn{2}{|c|}{$\begin{array}{l}\text { Direct effect of PACAP } \\
\text { on RACAP (c) }\end{array}$} & \multicolumn{5}{|c|}{ Indirect effect of PACAP on RACAP $(a b)$} \\
\hline \multirow[t]{2}{*}{ Coefficient } & \multirow[t]{2}{*}{$\mathrm{t}$ value $\mathrm{a}^{\mathrm{a}}$} & \multirow{2}{*}{ Coefficient } & \multirow[t]{2}{*}{$t$ value $e^{a}$} & & & \multirow[t]{2}{*}{ Point Estimate } & \multicolumn{2}{|c|}{$\begin{array}{c}\text { Percentile Bootstrap } \\
\text { 95\% Confidence } \\
\text { Interval }\end{array}$} \\
\hline & & & & & & & Lower & Upper \\
\hline $0.815^{* * 3 *}$ & 75.49 & $0.438^{* * * *}$ & 12.92 & Mediator & Knowledge Storage/Transfer & 0.377 & 0.234 & 0.574 \\
\hline
\end{tabular}

$* * * \mathrm{p}<0.001, * * \mathrm{p}<0.01, * \mathrm{p}<0.05$, ns: not significant (based on a Student $\mathrm{t}(4999)$, one-tailed test)

$\mathrm{t}(0.05,4999)=1.645158499, \mathrm{t}(0.01,4999)=2.327094067, \mathrm{t}(0.001,4999)=3.091863446$

Factor correction applied.

5000 Bootstrap samples. 